\title{
How Local Energy Initiatives Develop Technological Innovations: Growing an Actor Network
}

\author{
Esther C. van der Waal ${ }^{1, * \mathbb{D}}$, Henny J. van der Windt ${ }^{1} \mathbb{D}$ and Ellen C. J. van Oost ${ }^{2}$ \\ 1 Science and Society Group, Faculty of Science and Engineering, University of Groningen, P.O. Box 70017, \\ 9704 AA Groningen, The Netherlands; h.j.van.der.windt@rug.nl \\ 2 Department of Science, Technology and Policy Studies, Faculty of Behavioural, Management and Social \\ sciences, University of Twente, P.O. Box 217, 7500 AE Enschede, The Netherlands; e.c.j.vanoost@utwente.nl \\ * Correspondence: e.c.van.der.waal@rug.nl; Tel.: +31-62-921-0422
}

Received: 31 July 2018; Accepted: 30 November 2018; Published: 4 December 2018

check for updates

\begin{abstract}
Local energy initiatives are of growing interest to studies of grassroots innovation for sustainability. Some of these initiatives have developed novel technological solutions to fulfil local demand for renewable energy. However, whereas the upscaling and diffusion of grassroots innovations has been extensively discussed in the literature, their emergence has received very little attention so far. We will therefore focus on how energy initiatives can develop technological innovations by bringing together local actors and creating a fit to local circumstances. Grounded in actor network theory (ANT) and structured by concepts from Callon's sociology of translation, we studied two technologically innovative projects of a Dutch energy initiative. Through document analysis and interviews, we researched how these initiatives developed their innovations by forming networks of social, material, and discursive elements. We found that the outcomes of the innovation processes are very dependent on the networking capacities of the energy initiatives, as well as how well they fit with external circumstances and opportunities. The paper concludes with five lessons for grassroots technological innovation: form links with the local, extensively scrutinize plans, create tangible proof of alignments, position the project as beneficial to as many actors as possible, and adjust the level of ambition to the strength of the actor network.
\end{abstract}

Keywords: grassroots innovation; energy cooperatives; local energy initiatives; community energy; technological configuration; sociology of translation; actor network theory

\section{Introduction}

Many of the changes required to transform the energy system start with modifying existing configurations of technologies, services, or practices for use at a smaller scale [1]. Some of these innovations are developed by people and organizations located at the bottom of a system's pyramid, such as users, community groups, voluntary associations, and cooperatives. These bottom-up innovators create grassroots solutions for sustainable development that respond to the local situation and the interests and values of the communities involved [2,3], usually as matters of necessity and in response to challenges that are not addressed adequately by actors with more power [4].

The focus of this paper is on grassroots technological innovation by local energy initiatives that want to transition further towards a more sustainable energy system. Previous well-known examples of such grassroots innovations in the energy sector include the Austrian solar collectors and the Danish turbines developed by do-it-yourself builders and local craftsmen. Studies of these cases $[1,5,6]$ and of other user-designed and managed energy systems [7-12] demonstrate how energy consumers can take up new roles going far beyond passive consumption, and can be initiators, managers, developers, 
and co-developers of new technological solutions that are better adjusted to local values, needs, and desires, and that have a widespread impact on energy provision.

Some Dutch energy initiatives have also produced innovative technological solutions. Examples include an experimental church heating and ventilation system that increased energy efficiency as well as comfort, and a hydroelectric power station that has been integrated into a sluice gate [13]. These cases show that local energy initiatives tinker with technologies and methods for their implementation, leading to innovative arrangements of localities, actors, and technologies. De Vries et al. conceptualize these outcomes as "configurational user innovations", which they define as "user designed arrangements of loosely related sets of components" [13] (p.51). Innovation can thus be understood as the alignment of technical components, people, organizations, policies, business cases, physical characteristics of the site, skills, and local goals and values in a network.

Portraying innovations as networks of social, material, and discursive elements enables us to study how local energy initiatives connect these diverse elements into innovative configurations [3]. These networking processes are particularly interesting to study, because energy initiatives, which are often voluntary organizations, have limited resources and have few existing structures to guide their innovative endeavors. They need to find a way to develop from idea to implementation without a pre-existing innovation management structure as would be the case in many commercial environments, i.e., a systematic process from strategy building to implementation [14]. In addition, innovating requires experimentation and creates uncertainty, which exerts pressure on the relationships that need to be formed and maintained for a working configuration.

Accordingly, local energy initiatives have to build the structure to facilitate innovation almost from scratch and under challenging conditions. We therefore expect that the innovation process largely depends on how the energy initiatives engage in networking and we consider the following questions: how do local energy initiatives create a network that enables the development and implementation of innovative technological configurations? What conditions facilitate, and what conditions hinder, network building?

With a focus on network dynamics, we aim to contribute to a deeper understanding of how grassroots energy innovations emerge and gain robustness. A wide array of scholars use the multi-level perspective (MLP) and strategic niche management (SNM) to analyze grassroots innovations as niche dynamics [2,9,15-18]. Quite often these studies address how grassroots innovation niches can be strengthened by, e.g., sharing information and facilitating learning processes through intermediaries $[9,16,17,19]$.

In these studies, local energy initiatives are depicted as a niche, opposing and challenging the powerful actors in the prevailing energy regime. However, until now only limited attention is given to how innovations emerge from within local energy niches [20]. For addressing this question, the MLP and SNM framework are less suitable as they primarily focus on meso and macro level dynamics, whereas this paper aims to contribute insight into the local micro level network dynamics through which an innovative technological configuration is being shaped. Therefore, this paper takes a novel approach and uses actor network theory (ANT) as the theoretical lens. As we will argue in the next section, a micro level ANT analysis can add new insights to existing work on grassroots innovation dynamics.

\section{Theoretical Lens}

This paper analyses network construction from an ANT perspective to obtain a better understanding of how energy initiatives can align various elements into a network that enables the realization of an innovative technological configuration [20-23]. The ANT framework permits the interpretation of power and influence in networks at a micro level. It does not dichotomize structures and agents, nor humans and non-humans, but includes people, institutions, and the non-human realm as the scope for analysis [24]. Especially, because of the socio-technical nature of local energy projects, 
it is valuable to not only focus on human interaction, but also take into account the technical and other material aspects in the innovation process.

More specifically, we will use Callon's sociology of translation [21] as this framework provides us with concepts to study how energy initiatives can develop innovative energy configurations by building a network. A core concept is "translation," which Callon defines as the interactional process of connecting during which the actors' identity and their margins of manoeuvre are negotiated and delimited [21]. Callon has conceptualized this interactional process of connecting as phased (see Section 2.2) and these phases are particularly useful to understand various stages of network development within an innovation process. In this section, we will further introduce our theoretical lens.

\subsection{ANT and Energy Initiatives}

ANT follows actors during the development of a network [20]. As energy initiatives are the focus of our research project, we used their interactions as a starting point. Furthermore, ANT regards all elements in the socio-technical network as actants that possess agency. Possessing agency here means making or stimulating change in another entity or network [25]. The agency in a socio-technical network is shaped by the connections that constitute the network, and the durability and stability of these connections.

Agency can be exerted by human and other actants. In the case of a community energy project, human actants can, for instance, be the owners of a potential site for renewable energy (RE), and municipalities that can issue or deny building permits to energy initiatives or change land zoning plans. The category of non-human actants is diverse, including nature, technical, and material structures and texts (such as scientific accounts and laws) [25]. For example, a protected bat species living at the site of a proposed RE installation exerts agency through environmental protection laws and mechanisms for environmental impact assessment built into permit procedures, as well as through environmental non-governmental organizations (NGOs) representing its interests. The qualities of a site, such as its dimensions, soil type, and location relative to other infrastructure, impact the design options. For example, having a grid connection with enough capacity available at the site saves costs and makes it easier to achieve a viable business model. As these examples show, non-human actants possess agency and influence the success of a community energy project. They need to be taken into account as actants to be followed during network construction, just like human actants.

\subsection{Analysing Network Development}

In following network development, ANT is not primarily concerned with mapping only the interactions between actors, but rather with mapping "the way in which they define and distribute roles, and mobilize or invent others to play these roles" [22] (p. 285). ANT characterizes this process of actors struggling over inclusion within particular networks as translation. Translation is the process of making connections between a multitude of elements involved in a system and their meanings, such that they can be related in a socio-technical network [23]. It is therefore about relating things that were previously unconnected. Consequently, the identities of the actants involved and the meanings that they attach to various aspects of the project are fluid and can be intentionally influenced by actors in the translation processes. Callon [21] argues that such translation dynamics occur in four phases: problematization, interessement, enrolment, and mobilization. We will elaborate on these terms below, using examples from the community energy context.

The first phase of network building is the problematization phase. As the initial network builder, the energy initiative needs to problematize the situation and make itself indispensable to other actants by creating an obligatory passage point. This obligatory passage point can be established by firstly defining a problem with a certain urgency and importance, and then convincing the desired partners that this problem can only be resolved by cooperating with the energy initiative. An important means 
through which energy cooperatives can do this is by defining themselves as a necessary partner to meet sustainability targets.

After creating a shared problem definition, an energy initiative needs to create interessement, which is a series of processes by which the energy initiative can lock actants into the roles that it proposes. In this phase, the interest of the actant is defined, and potentially also redefined if the actant succeeds in negotiating inclusion in the network on different terms than the energy initiative proposed.

Interessement is realized by the initiative through interposition, which means putting itself or a third party between two actants, often to intervene in their activities and bend their actions to another cause. This is realized with the help of so-called interessement devices, which can be technologies but also policies, laws, or resources such as money. These devices are used to stabilize the connection between the energy initiative and the actant that it wants to engage, and weaken possible links between the actant and entities which may threaten the alliance. The interessement device is of particular importance to the energy initiative with respect to actants for whom the energy initiative cannot truly be an obligatory passage point.

Subsequently, if interessement is successful, the energy initiative has to enrol actants in the network by interconnecting the various roles into a productive network. Interessement devices are powerful tools for structuring the relationships in a socio-technical network. An example of an interessement device is a grant, which connects the government that allocates it, the recipient energy initiative, and the actants, such as a project developer or a consultancy firm conducting feasibility studies that the energy initiative pays for using the grant money.

Finally, mobilization refers to making "entities mobile, which were not so beforehand" [21] (p. 14). For actants that first need to be detached from other actants, this phase also refers to this displacement and necessary changes in alliances. However, the connections made in a socio-technical network can be contested at any moment, making the mobilized state a potentially volatile one [21].

\section{Methodology}

Using a case study design, we empirically studied the translation dynamics of two local energy initiatives that were in the process of developing an innovative energy configuration in their municipality. From beneficial and unbeneficial moments of translation along the project development process, we can learn how and under what conditions energy initiatives can engage with potential facilitators, align them with their innovation projects, and keep themselves dissociated from actants that obstruct their progress.

\subsection{Conceptualization of Core Concepts}

This paper focuses on the development of innovative technological configurations in which local energy initiatives play a key role. It is therefore important to elaborate on how we will conceptualize the two core concepts.

We use the conceptualization provided by Boon to define local energy initiatives, and characterize them as initiatives "initiated and managed by actors from civil society, that aim to educate or facilitate people on energy use and efficiency, to enable the collective procurement of renewable energy or technologies, to provide, generate, treat or distribute renewable energy derived from various renewable resources for consumption by inhabitants, participants or members who live in the vicinity of the renewable resource or where the renewable energy is generated" [26] (p. 10).

Based on the work of Peine and Fleck, we define innovative technological configurations in this research as new and productive alignments between local actors, RE technologies, and localities made under prevailing socioeconomic, spatial-physical, and institutional circumstances $[27,28]$. In line with Fleck, we use the notion of technological configurations instead of technologies to emphasize that local energy projects do not focus on purchasing RE technology and using it off the shelf; instead, we center on the setup or configuration shaped by the energy initiative to serve the local context [27]. Therefore, the identity of a technology gets shape during the configuration process, and evolves during project 
development as a result of learning processes. Other parts of the configuration, such as the actors executing project development and the site where the configuration is implemented, also evolve [28].

We consider a technological configuration innovative when it yields any kind of value (social, economic, or environmental) "in the form of new or improved functionality or quality, reduced cost, better or more widespread availability (i.e., bringing a new tool or capability to a location where it had not been available before), ... [price], or some combination of any or all of these" [14] (p. 12).

\subsection{Case Study Method}

To analyze how energy initiatives create a network with the agency for the implementation of an innovative technological configuration, we looked closely at two projects through a case study design. The case study design allowed us to research the project-level network construction processes during project development, and to identify beneficial and less beneficial translation attempts: the events in which connections are made and lost. The cases illustrate how energy initiatives can organize agency by defining and distributing roles and making other parties play these roles, to build a technologically innovative energy configuration.

We increased the external validity of our findings by selecting energy initiatives that had to start their innovative projects from scratch (neither finance nor location were provided upfront, which is the starting point for most local energy initiatives). By doing so, we gained insight into the whole process of network construction and translation and captured a set of common steps that virtually all technologically innovative energy projects need to go through: invention, testing the technological configuration, securing a location, finding investors and other partners, and obtaining the necessary permits and grants.

As a first exploratory step, an expert in the field of community energy was interviewed to identify potential cases. After a round of initial conversations with representatives from several of the suggested energy initiatives who were contacted by email, two projects were then selected for the richness of their networks and their interactions in these networks: the BrummenEnergie solar park, which is under development at the paper landfill site in its eponymous municipality, and the planned floating solar park of Stichting Betuwe Energie. These two cases represent two different ways that a new technological configuration can be realized: one case shows how improving an existing technology can start within a community initiative, and the second case shows how an innovative configuration can be achieved by collaborating with the developer of an innovative technology in a pilot study (these ideas are introduced further in Sections 3.2.1 and 3.2.2).

While neither of these two projects have reached the implementation phase, both have been through almost the entire project development process and are now at the point where they only need to secure their feed-in tariff Stimulation regulation Sustainable Energy production+ (in Dutch: Stimuleringsregeling Duurzame Energieproductie+, SDE+), which is allocated twice a year. Our analysis of the translation dynamics therefore focuses on the initiating and developmental phase of the two innovative technological configurations and leaves out the implementation phase. However, the most important alignments have to be made before implementation. Once the subsidy is allocated, the energy initiatives can activate the actants needed for implementation relatively easily, as the project has then truly proven its economic viability.

\subsubsection{BrummenEnergie: A Solar Park on a Local Landfill Site}

BrummenEnergie is working on a solar park to provide energy for approximately 1200-1400 households. It occupies 12 ha situated at a paper landfill site in Eerbeek, a settlement in the municipality of Brummen. Developing a solar park on a landfill site poses legal challenges as this complementary land use initially conflicted with the Landfill and Soil Protection Decree 1993 (Stortbesluit bodembescherming), but besides the legal dimension, the technical dimension of this project is also complex. Instability of the ground due to subsidence of the paper waste meant that regular solar PV panels and a lighter and more experimental solar film were both considered from an early stage. 
The first option was a 15,000 panel and roughly 4.5 MW PV installation with a stabilizing foundation. The alternative was an experimental solar film generating about $100 \mathrm{kWh} / \mathrm{m}^{2} /$ year, consisting of lightweight and flexible thin-film silicon solar cells on long foil substrates. This film is very flexible, making the technology applicable for covering rooftops and facades, for instance, and potentially also a landfill site. The amorphous nanocrystalline silicon tandem cells yield product efficiencies exceeding $10 \%$ (commercial solar panels yield from $9 \%$ to $21 \%$ [29]). Although the yield would not be very high, thin-film is less expensive per $\mathrm{m}^{2}$ and could cover a greater surface than solar panels, which would partly make up for the efficiency difference with the panels. The difference in the potential yields would also be nullified because of a grid limitation. The socio-technical network developed while working on this project was therefore strongly focused on finding the combination of an appropriate technology and a viable business model that could fit within the regulations for managing the landfill.

\subsubsection{Stichting Betuwe Energie, a Floating Solar Park in a Sand Excavation Lake}

Stichting Betuwe Energie is in the process of developing a 1.4 ha floating solar installation consisting of 10,800 panels on lake Eisenhower in Elst, a settlement in the municipality Overbetuwe. Its calculated capacity is $1.9 \mathrm{MW}$ and the electricity will be supplied to local industries. The project was started by a retired bank manager, who cooperated closely with the municipality for years as a sustainability consultant, advising residents on solar panels for their homes through his solar collective Overbetuwe foundation. The technology for this floating solar field was developed by an acquaintance of his, a retired engineer, who developed the concept of floating solar PV by adding an innovative mechanism permitting the installation to follow the sun, to increase its yield by about $35 \%$. The installation normally turns 180 degrees (with a maximum of 270 degrees) in twelve hours, while also continuously adjusting the angle of the panels to obtain perpendicular irradiation during the daytime.

While the bank manager worked towards the establishment of a cooperative to develop the project, the engineer continued improving the technology and established a start-up company. The floating solar project is therefore dependent on the development of two partly interwoven socio-technical networks: one around the implementation of the project and one concerned with the development and marketization of the solar tracking technology.

\subsection{Data Collection and Analysis}

The empirical data was retrieved from three types of sources: local energy initiative websites (e.g., various online news updates), internal documents provided on request by the local energy initiatives, and semi-structured interviews. As displayed in Table A1 in Appendix A, a total of thirteen semi-structured interviews were conducted with actors involved in the development of the two projects (either by phone or face-to-face). The role of non-human actants has been analyzed from the perspective of the various human stakeholders in the project.

The interviews explored the various moments of translation during project development. They were structured to answer the following questions regarding the translation processes within the cases and also informed the structure of the results section:

1. Problematization: (i) which problem definition underlies the project and (ii) how has it been formulated?

2. Interessement: (i) what roles were identified by the local energy initiative, (ii) what are the resources associated with these roles, (iii) at which stage did these roles need to be fulfilled, (iv) which interessement devices were used by the local energy initiative and other actors, and (v) how were the actors persuaded by the various interessement devices to play the roles proposed to them?

3. Enrolment: (i) how were alignments achieved between the human and non-human members of the network to further the innovation process, and (ii) how did interessement devices help to interrelate parts of the network? 
4. Mobilization: (i) which actants were mobilized, (ii) how durable was the mobilization, and (iii) are there any future threats to this mobilization?

All of the data were analyzed thematically using the translation phases as guiding concepts. Where possible, the data were triangulated by using various sources to collect specific information (interviews, websites, and documents) and by repeating the same semi-structured interview with multiple interviewees. Moreover, the interpretation of the data was checked with the interviewees.

\section{Results}

In this section, we describe the evolving socio-technical networks developed by BrummenEnergie and Stichting Betuwe Energie to create an innovative technological configuration using the sociology of translation as a lens. The reconstruction of the translation dynamics is based on the operationalization of the translation phases in the methodology and the empirical data obtained from documents and interviews.

\subsection{BrummenEnergie: A Solar Park at the Paper Landfill}

\subsubsection{Problematization}

Within a year of its foundation in 2012, the cooperative and the municipality began a series of meetings with other municipalities and cooperatives in the region to identify locations for developing RE projects co-financed by available provincial funds. The 12 ha paper landfill site presented itself as a potential location to the chairman of the Brummen cooperative when he passed it on his racing bike. He explained: "If you did not know it was a landfill site, you cannot really see it because of the overgrowth. I was aware of the landfill and thought that it was a shame that it was not covered with solar panels."

Shortly afterwards, he approached the director of the landfill. Because he had worked for the paper industry in Eerbeek earlier in his career, he knew the company that managed the landfill, and which person to approach. The landfill director was interested in the idea of developing a solar park at the landfill site, not only because it would contribute to local sustainability, but also because a solar project at the landfill site could possibly play a role in solving the technically complicated and very costly problem of covering the landfill site. Owing to waste disposal regulations implemented in 1995 [30], the landfill site had been closed for over fifteen years. As part of the post-closure care guaranteeing the safety of the environment, the Landfill and Soil Protection Decree [31] — a national decree implemented by the provinces-requires that the landfill site be covered. Even though the waste is non-hazardous, according to this Decree, the Eerbeek landfill site must be fully closed off to stop the infiltration of rain in the waste materials that could lead to contamination of groundwater, soil, and air. Such an impenetrable cover consists of various layers of high-tech materials and represents a multimillion-euro investment, and the landfill director was investigating possibilities to create an alternative and preferably less expensive cover.

Furthermore, the covering of the paper landfill site was also still pending, because the paper waste at the landfill was still settling, and because of significant but unpredictable and variable subsidence, varying between 1 and $3 \mathrm{~m}$, extra stabilization measures were required before it could be covered. Otherwise, the subsidence might well cause the covering layers to tear, making it impossible to guarantee an impenetrable cover in the long run.

Facing the obligation to comply with the Landfill and Soil Protection Decree, the opportunity to develop a solar park at the landfill site was an argument for its director to strengthen his case in favor of alternative and less expensive coverage. The opportunity to install a large solar park could be used to connect with other policies and regulations to provide a new way to approach finding legal space for alternative covering. 
As a result of the collaboration between the cooperative and the landfill director in the problem definition, the role of the solar panels was therefore broadened from merely increasing local RE production to also covering the local landfill.

\subsubsection{Interessement and Enrolment}

The chair of BrummenEnergy and the director of the landfill site identified the roles that were needed to continue the project successfully in the next phase. They then tried to enrol actants corresponding to these roles in their network.

\section{Bringing in Knowledge: A University and an Innovation Platform}

First, they sought a source of knowledge capable of outlining the legal, technical and economic feasibility of ordinary solar panels and a new lightweight solar thin-film developed in the region.

Before retiring, the chair of BrummenEnergy had worked at the University of Applied Sciences of Arnhem and Nijmegen as a business economist. He continued to be in contact with his former colleagues, so he contacted them to see whether they could have students explore their questions regarding the feasibility of the two options for a solar park on the landfill as graduation projects. This resulted in four graduation projects in 2013: one project in business economics, one in mechanical engineering, and two legal projects.

Alongside the students, the chairman of BrummenEnergy and the director of the landfill approached a starting solar thin-film company that they knew for information on the technical and economic specifications of the product. The students' feasibility studies based on these figures showed that this film would be technically simple and would make a good return on investment. However, the legal research showed that the Landfill and Soil Protection Decree was an obstacle to establishing a solar park on the paper landfill site. As the landfill director stated: "The Landfill and Soil Protection Decree has been designed so strictly that new developments do not get a chance."

Not long after these studies were completed, further opportunities for a pilot project were explored as part of a strategy by the Province to promote the solar thin-film company. The solar thin-film company was the anticipated centerpiece of the Energy Valley campus for innovative companies in the field of environmental technology that the province of Gelderland was developing near Arnhem. The solar film had just reached the point of being ready for market entry, and the company was looking for a launch customer to scale up production and begin making a profit. The solar project at the landfill site had the potential to be such a launch customer that would justify the extension of the thin-film production facility. To aid the development of its business, the solar thin-film company was in contact with the Kiemt foundation. This is a platform financed by the Province of Gelderland to transform the province into the Dutch center for energy and environmental technology and bio-based economy. Kiemt had received the students' reports, which acted as interessement devices, binding Kiemt to the project in the role of external mediator and facilitator. Kiemt thought in terms of "chances and developments" and helped to smooth the cooperation by mediating the project development from an external perspective, which helped to overcome difficulties encountered when the project was in danger of stalling (interview municipality of Brummen).

From this point onwards, the case manager from Kiemt, the director of the landfill site, the chair of the cooperative, the solar thin-film company, and at times representatives of the Province and municipality, held regular meetings. Moreover, thanks to the project's good prospects, the cooperative received a municipal subsidy to hire a project developer experienced in supporting cooperatively developed solar parks. As a group, they identified opportunities to get the legal permission and finance for a pilot.

\section{Towards a Pilot: Legal Permission and Funding}

To avoid the strict coverage regulations of the Landfill and Soil Protection Decree, the group started a process proposed by Kiemt to fast-track the project via the Crisis and Recovery Act (Chw) [32]. 
The Chw was developed in response to the economic recession in the late 2000s and early 2010s and aims to stimulate the economy and employment in the construction sector and the economy in particular. It shortens the approvals process for infrastructure projects and facilitates innovative projects by providing them with exemptions from regulation, where possible. As a large solar park at the landfill site would justify expanding the production of the solar thin-film, the project would stimulate the economy by creating up to 30 jobs at the solar thin-film company [33]. Furthermore, this method for covering landfill sites was estimated to have a replication potential of 10,000 ha across Europe, which offered the prospect of further growth for thin-film production [33].

The municipality now adopted an advocating and connecting role and took up the Chw application with the Province. The Province subsequently applied to the Ministry of Infrastructure and Water Management for an exemption to the relevant sections of the Landfill and Soil Protection Decree. A policy officer from the municipality of Brummen illustrates: "We did need to persuade the permit allocation division at the Province.... The Provincial deputy has helped to get the parties [permit allocator and inspection division of the Province] on the same page."

After a process of lobbying, the project was included in the tenth tranche of the Chw Implementation Decree in September 2015, as an innovative combination of electricity generation and waterproof landfill site covering. As a result, the Chw created an interposition between the landfill site and the Landfill and Soil Protection Decree. Provided that the groundwater quality does not deteriorate, the Province must now propose a new deadline for the covering, required by the Decree by 2040 .

Parallel to this legal process, grant options for a pilot were explored. After missing out on a national grant to encourage innovative energy technologies, the project was selected for a provincial grant of EUR 160,000 for a pilot in late 2015. This grant came from a program called Gelderland's dimensions (in Dutch: Gelderse Maten), which targeted pilot projects exploring energy generation or savings in local projects including citizens, companies, municipalities, and non-governmental organizations. The grant functioned as an interessement device to further lock the partners into the project development network and strengthened the ties between parties through financial agreements regarding the pilot.

\section{Implementation of the Pilot}

For the pilot, $4000 \mathrm{~m}^{2}$ of the landfill site was cleared, levelled, and stabilized with waste material from blast furnaces (clinker). The director of the landfill site consulted an earthworks company, which was included in the growing support network, for knowledge on stabilization of the landfill site. After preparation of the surface, $5 \mathrm{kWp}$ solar thin-film and $3 \mathrm{kWp}$ lightweight solar panels were installed. These newly available lightweight solar panels were expected not to sink into the waste. For this application, the solar thin-film was combined with a geo-textile that had been developed in cooperation with the thin-film company for a previous project. The geo-textile would stop rainwater infiltration and provide an alternative way to seal the landfill. The pilot would run for two years and would test the performance of the solar thin-film as well as the stability of the foundation that the solar panels and thin-film were placed on. The test site was officially opened in June 2016.

After a year, the solar thin-film was found to have already degraded severely, and was not advanced enough to be adapted effectively with the physical conditions at the site. Another setback was that the solar thin-film company had disassociated itself from the pilot in the meantime, which excluded the possibility for cooperating further on a more durable hybrid of the geo-textile and the solar thin-film. The reason for the disenrolment was the film producer's dissatisfaction with the opportunities that it had obtained from the Province to develop its business. During the pilot, the company had found an opportunity to upscale and to move production of the thin-film abroad. At this point, the role of the Kiemt innovation platform in the project also ended because the project was no longer about testing and eventually helping to upscale an innovative energy technology. However, the pilot had shown that the foundation method tested using blast furnaces clinker supported the lightweight solar 
panels, and thus locally, the innovation process to establish a solar park on an unstable landfill site could continue. However, as the solar thin-film production and its foreseen economic benefits were no longer part of the project, it was unclear whether the exemption to the Landfill and Soil Protection Decree through the Chw could still be used.

\subsubsection{Mobilization}

To the surprise of the project group, the Province now identified an article in the Decree which could be read as supporting alternative coverings, making the project legally viable. Ultimately, the Province was able to create alignment between the Decree and the solar park and created legitimacy for the project through the Decree.

With this uncertainty resolved and the environment permit granted by the Province after a shortened procedure approved by the municipality, the project group was able to apply for the SDE+ tariff in the autumn of 2018. If this RE subsidy is allocated, the construction of the solar park will be able to commence, as the project developer has the available investment capital to secure a bank loan for the project. Not obtaining this feed-in-tariff is the biggest threat to the project at the moment, as it is not viable without it. Because the scheme is substantially oversubscribed, projects that use a form of technology (e.g., solar) that needs the lowest subsidy/energy output are the first to be funded. The scheme can thus achieve an economically efficient transition and maximize the capacity installed. The allocation of this subsidized feed-in tariff is only done biannually, so an initial rejection might cause tension within the network because it would cause significant delays and it would continue to be uncertain as to whether the subsidized tariff would be allocated on the next attempt. However, the time, effort, knowledge, and money that have already been invested and the contracts that are in place (e.g., for use of the site and the project development contract) make it unlikely that the cooperative, landfill manager, or the project developer would disassociate from the network unilaterally. Finally, the solar thin-film developer has shown that disenrolment need not be permanent, as it has renewed its interest in the landfill site to test a new prototype of its film.

\subsection{Betuwe Energy: A Floating Solar Tracking Installation on the Lake}

\subsubsection{Problematization}

The idea for an innovative floating and rotating solar installation arose in 2011 during the implementation of the municipality of Overbetuwe's climate plan, which aims for $14 \%$ RE by 2020 (on par with the national target). A retired sustainability consultant from the municipality volunteered to investigate options for the solar park. As wind turbines face resistance in the municipality, a considerable surface area was needed to generate the RE required to realize the climate plan mainly using solar.

In a meeting with the municipality about the implementation of the climate plan, an alderman mentioned Lake Eisenhower to the sustainability consultant. The lake is owned by the municipality and an earthworks company located next to the lake. It is not currently in use as it is polluted by past industrial activities. This suggestion started a process of redefining Lake Eisenhower from a useless, polluted lake into a large area available for solar RE generation.

Looking online at floating solar systems, the sustainability consultant reckoned that it should be possible to get a solar panel installation to rotate from east to west during the day to maximize yield. As he lacked the technical knowledge to explore how to implement such a system, he contacted an acquaintance, a retired mechanical engineer with whom he sang in a choir. As a technical enthusiast, the engineer was up for the challenge and started what he called a "project of combination and deduction," in which he integrated his professional experience with floating objects and other technical knowledge that he had gained over the years. Within a short time, he had designed a structure that rotates during the day and also tilts to maximize yield by creating perpendicular irradiation. Furthermore, the engineer added two more features: a fish-pond-like bubbler system to keep the 
water from freezing in winter and rollers to prevent birds from landing on the installation and soiling the panels.

From this point onwards, the engineer worked on refining the design, and the sustainability consultant started to further explore the requirements for developing a floating solar park and institutionalizing the initiative.

\subsubsection{Interessement and Enrolment}

The municipality was positive about the plan to use the lake but did not want to take on the role of landowner in this project. It wanted to avoid potential accusations of providing state aid and having its procurement procedures challenged, and therefore suggested that the quickest and easiest solution would be to develop the solar park on the lake owned by the dredging company, with their permission.

Concretizing Plans: Confirming the Location and Assessing Feasibility

Through their professional backgrounds, the two initiators were both already in contact with the dredging company. The sustainability consultant was part of the sustainability committee for the industrial area and the engineer was still active as a consultant to the company after having retired from working there. The dredging company responded positively to the plan because it was aligned to their vision for adding social value to their projects. As a representative of the company illustrates: "We would like to offer our resource - sand- $\mathrm{CO}_{2}$ neutral. Therefore, we are exploring renewable energy [in various ways]." Moreover, the dredging company owns various excavations where the project could be replicated if successful.

After various talks, the dredging company decided to make the site available for free to facilitate a more attractive business model. A normal profit margin was needed for this project because the sustainability consultant knew from experience that most businesses would only invest if some return on investment could be expected. As the businesses in the local industrial area were expected to adopt both the role of investors and electricity consumers, their participation was an important condition for project development.

With the location secured, the sustainability consultant and the engineer applied for a provincial grant of EUR 25,000 to finance pre-development costs in early 2015. They noticed that it is hard to secure a subsidy as a newcomer: "There are many like-knows-like networks in which subsidies are allocated and it is hard to enter these networks.... [Having relevant contacts in your own network] helps" (interview SBE \#2). However, they were successful, and hired an external agency to verify the engineer's design and to perform an economic feasibility study. This study was completed in nine months and showed that the project was both technically feasible and economically viable.

The Environmental Permit: A Facilitative Municipality

In autumn 2015, the consultant and engineer applied for an environment permit at the municipality. As the municipality was supportive, it established a special committee to consider all of the aspects of the project that needed to be reviewed at once. They first needed to prove that the RE installation would not harm the wildlife in and around the water. With the money left over from the provincial grant, the sustainability consultant and the engineer had an ecological study performed that demonstrated that local wildlife, such as the ducks and fish, would not suffer from the solar park. Second, the lakeshore and surrounding area contained archaeological remains from the Roman period, and any building activities involving pile driving would require an archaeological study. The initiators did not want to be delayed and inquired of the municipality whether an archaeological study would also be necessary if the required piles were to be located a few meters offshore. As a permit to use the sand excavation site had already been given, this solution avoided the need for an archaeological study. Finally, the municipality requested a visual impression of the solar park because it was such a novelty that they could not assess the expected spatial impact. The sketches and 3-D designs prepared 
by a graphic designer showed that the 1.4 ha installation would be barely visible from the shore, as it was fairly flat and would rest a couple of hundred meters offshore.

This productive collaboration with the municipality led to the very rapid completion of the permit procedure, which happened within two months. The sustainability consultant stressed the benefits of the municipality's support: "Lingewaard Energie [a cooperative from a neighboring municipality] has already been working for a year on getting the permit for their floating solar park. Here, the municipality's various departments are all on the same page."

The publicly announced permit application sparked a fair amount of media attention, even before the environment permit was granted. This started with an article in a regional newspaper, which was picked up by a number of national newspapers and led to an invitation for the engineer and the sustainability advisor to discuss the project on national television. Because of the media attention, the Dutch government Department for Waterways and Public Works (RWS) learned about the project and invited the engineer to include the technology in a pilot project with three other floating solar technologies. This pilot was realized through a consortium initiated for testing the performance of floating solar technologies in semi-open water with higher waves at the Port of Rotterdam dredging depot. This consortium, called the National Consortium Solar on Water (In Dutch: Nationaal Consortium Zon op Water), consists of government bodies, knowledge institutions (Energieonderzoek Centrum Nederland and Toegepast Natuurwetenschappelijk Onderzoek, joining as the Solar Energy Application Centre), and energy and water sector incumbents, and has invested in the pilot as it foresees a future in which solar parks at sea will be technically and economically feasible and can be combined with wind parks. Therefore, the announcement of the application for the environment permit unintentionally acted as an interessement device linking the solar tracking technology to the pilot, which started in September 2017 and is still ongoing. The pilot installation has since survived several heavy storms ( $\mathrm{Bf} 10$ and 12), and a few modifications to the installation have been made to further improve its functioning.

Institutionalizing: A Start-Up, a Foundation, and a Cooperative

At this point, the floating solar panel technology had become part of a start-up established by a turnkey solar installation company and a family business in winches, special-purpose machines, and hydraulics. The engineer felt that a commercial environment was needed to bring the technology to the market. However, he wanted to enjoy his retirement and was not interested in a role as developer. The hydraulics company was interested in the solar tracking technology because of its regional roots, the company's belief in bottom-up innovation, and the technological concept itself. These factors convinced them that it was possible to scale up and bring the technology to the market. Furthermore, they added that it was also about having the guts to invest in an idea that feels promising: "At a large company such innovations often strand in the bureaucracy. You will get all kinds of tables and ratios to calculate the risk and potential benefits. Even the brightest ideas will then strand if they are not well quantifiable. You need to dare to become part of it and invest."

After the transfer of the intellectual property, one engineer remained involved as a consultant but entrusted the start-up with developing the pilot in Rotterdam's harbor and the further marketization of his technology.

Meanwhile, the sustainability consultant looked for a way to institutionalize the project. He brought together a group of acquaintances with backgrounds as varied as accountancy, law, and local politics. Contrary to some other initiatives they had seen, the group wanted to work on the solar project as volunteers. One of the members stressed: "We have seen projects in which initiators paid themselves and the project stranded when the subsidy was finished. We do it unpaid and because we like it." In December 2015, they decided to establish a foundation to pursue energy sustainability in the Overbetuwe municipality, to create a subsidiary cooperative for the floating solar installation and, later, to establish new cooperatives for potential future projects. The rationale behind this umbrella 
construction was that people could participate in a specific cooperative and corresponding project. Members of the cooperative were not required to be engaged with all the foundation's activities.

With the site secured, the feasibility studies performed and the environmental permit granted, the foundation was ready to apply for an SDE+ feed-in-tariff on behalf of the cooperative. Having the subsidy would further strengthen the network, as the subsidy could function as an interessement device. It would enable a financial tie between the cooperative and the start-up, and would further activate investing businesses. However, a subsidy was not granted in the first two attempts. The first time, the paperwork was not completed on time despite outsourcing part of the preparation to a subsidy advisory consultancy. The second time, the feed-in tariff that the foundation applied for was too high to create enough interposition between the project and its competitors to have the subsidy allocated. The foundation aims to remedy this in the next attempt.

\subsubsection{Mobilization}

Whether the elements in the actor network will be mobilized to start implementation depends on the allocation of the SDE+ subsidy. At the time of writing, the foundation is working on its third attempt to secure this subsidized feed-in tariff and will learn whether the SDE+ will be allocated in the summer of 2018. The chair of the foundation expects that the cooperative will receive the subsidy this time, but estimates that it will then take roughly another eighteen months to finish the project. The investors that have promised to contribute financially must be mobilized to actually provide the promised funding.

In the meantime, the start-up keeps developing the technology and its business model and exploring projects with potential future clients. It is therefore not entirely certain whether the technology will be available at the moment that the cooperative is ready to proceed, which might cause it to need to find alternative floating solar options on the market.

Other parts of the innovation network, however, are more stable. The municipality and the dredging company are securely mobilized, and the environment permit and the contract with the dredging company regarding the use of the lake are tangible legal documents. However, it is uncertain whether the future cooperation between the foundation and the municipality will be as smooth as it was within this project. Recently, the relationship between the foundation and the municipality has cooled considerably because of political changes.

\subsection{Overview of the Case Studies}

In this section, we will provide a schematic overview of the main findings from the two case studies. The translation phases have been used to structure the overview presented in Table 1.

Table 1. A schematic overview of the main findings from the case studies per translation phase. Abbreviations of the phases: PD (problem definition), I \& E (interessement and enrolment), and M (mobilization).

\begin{tabular}{|c|c|c|}
\hline & Case 1: Solar on the Landfill Site & Case 2: Floating Rotating Solar \\
\hline \multirow[t]{4}{*}{ PD } & Aspects: & \\
\hline & $\begin{array}{l}\text { Increasing local RE production } \\
\text { (municipality and cooperative) }\end{array}$ & $\begin{array}{l}\text { - Increasing local RE production } \\
\text { (municipality and sustainability consultant) }\end{array}$ \\
\hline & $\begin{array}{l}\text { - Unlocking a space for large-scale solar } \\
\text { (municipality and cooperative) }\end{array}$ & $\begin{array}{l}\text { Unlocking a potential space for large-scale } \\
\text { solar (municipality and } \\
\text { sustainability consultant) }\end{array}$ \\
\hline & - $\quad$ Covering the landfill site (landfill director) & - Improving an existing technology (engineer) \\
\hline
\end{tabular}


Table 1. Cont.

\begin{tabular}{|c|c|c|}
\hline & Case 1: Solar on the Landfill Site & Case 2: Floating Rotating Solar \\
\hline \multirow[t]{4}{*}{ I \& E } & \multicolumn{2}{|c|}{$\begin{array}{l}\text { Policy and regulation, personal and professional networks, knowledge, financial means, legal and } \\
\text { governance authority, space, communication skills, networking skills, and time. } \\
\text { Interessement devices: }\end{array}$} \\
\hline & $\begin{array}{l}\text { - Student studies (linking innovation } \\
\text { platform, cooperative, landfill company, } \\
\text { province and municipality, and solar } \\
\text { thin-film company in a working group) }\end{array}$ & $\begin{array}{l}\text { - Feasibility study (linking technology, } \\
\text { engineer and start-up, and further } \\
\text { institutionalization by developing into } \\
\text { foundation and cooperative) }\end{array}$ \\
\hline & $\begin{array}{l}\text { - Municipal and provincial grants (enrolling } \\
\text { project developer, and strengthening } \\
\text { interlinks in working group) }\end{array}$ & $\begin{array}{l}\text { - Provincial start-up subsidy (linking graphic } \\
\text { designer and the agency performing the } \\
\text { feasibility study to the consultant } \\
\text { and engineer) }\end{array}$ \\
\hline & $\begin{array}{l}\text { - Exemption to Landfill and Soil Protection } \\
\text { Decree via the Chw (exempting landfill } \\
\text { side from the Decree) }\end{array}$ & $\begin{array}{l}\text { - Public announcement of application } \\
\text { environment permit (linking the start-up } \\
\text { and engineer to the floating solar pilot test) }\end{array}$ \\
\hline \multirow[t]{5}{*}{$\mathbf{M}$} & \multicolumn{2}{|l|}{ Durability: } \\
\hline & \multicolumn{2}{|c|}{$\begin{array}{l}\text { - The initiators were mobilized at all stages and the other actants were only mobilized during a } \\
\text { certain phase or from a particular moment. }\end{array}$} \\
\hline & \multicolumn{2}{|c|}{$\begin{array}{l}\text { - Some actants remained mobile after the mobilization (e.g., the project developer in the landfill } \\
\text { site case) and others disassociated after they fulfilled their role (e.g., the graphic designer in the } \\
\text { floating solar case). }\end{array}$} \\
\hline & \multicolumn{2}{|l|}{ Threats: } \\
\hline & $\begin{array}{l}\text { - } \quad \text { Rejection of application for the } \\
\text { SDE+ subsidy }\end{array}$ & $\begin{array}{l}\text { Rejection of application for the } \\
\text { SDE+ subsidy } \\
\text { Development of the start-up and floating } \\
\text { solar technology } \\
\text { - Mobilizing investors }\end{array}$ \\
\hline
\end{tabular}

\section{Discussion and Conclusions}

In this final section of this paper, we draw conclusions and core lessons for successful socio-technical network development by technologically innovative energy initiatives from the empirical results.

From the development of the actor networks in the case studies, we can conclude that local energy initiatives initially develop innovative technological configurations on an ad hoc and step-wise learning as we go basis, in a process that becomes more structured as the projects progress. The research supports our hypotheses that innovation increases the difficulty of project development, and that the outcomes of the innovation processes are very dependent on the networking capabilities of the energy initiatives. We will explore this in more detail in this section. We present and discuss our five main conclusions on how local energy initiatives can create actor networks in which the alignments between actants build up to functional innovative technical configurations. While the explanatory power of the two cases is certainly limited, we researched the literature on grassroots innovation to see whether our conclusions fit with what has previously been found.

\subsection{Innovating by Linking to the Local}

Local energy initiatives develop RE projects through seizing "local opportunities for synergies and trade-offs with local actors, such as entrepreneurs, public bodies or citizens," and by linking to the systemic functions of the "local landscape such as agriculture, water treatment, social care, housing and leisure" [34] (p. 175). The energy initiatives studied also started from an awareness of 
the local circumstances and sought to develop their project to fit with these circumstances and to create synergies by aligning their goals with those of other local actants where possible. At various points in the translation process, this encouraged other actants to support the planned innovation. Furthermore, while we do not want to imply that this is by any means a necessary result of grassroots innovation, in both cases, the resistance of users of the area to the project played no role (and is therefore absent from the results). Other works have also found a positive effect of local involvement on RE attitudes $[35,36]$.

\subsection{Unknowns Require Increased Scrutiny}

Rigorous feasibility assessments that can convincingly demonstrate the potential to create successful alignments and functioning innovation are required within projects in which an innovative technological configuration is developed. Tangible products, such as studies performed by students or a feasibility report prepared by a recognized specialist, can function as strong interessement devices to get other actors with additional resources, such as knowledge, further networks, and capital, on board.

Strategic niche management literature has already shown that resourceful networks are key to the development of energy innovations [15]. In the case of the energy initiatives studied, such resourceful actors primarily come from existing professional and personal networks in the early phases of the innovation process. In the later stages, they come from a wider network in which contacts from the partnering actors' networks and unfamiliar actors are also engaged. In addition to landowners, investors, and experts of various kinds, local government [37] and intermediaries [16] are especially valuable partners in helping to build necessary ties between the members of the actor network that are hard to align.

\subsection{Making Alignments Visible Is Key}

When experimental technologies or set-ups are used, assessing their feasibility through calculations and drawings alone is often insufficient, meaning that a proof of concept is needed to prevent invisible or hidden misalignments from emerging after full-scale implementation. As alignment is formed in an interactional process with incomplete information, an actor might think that certain parts of the innovation network are aligned, whereas in reality, they are not. In the case of the paper landfill site, the connection between the solar thin-film and the physical conditions at the landfill was such an invisible misalignment. The film did not react well to the weather conditions and soon started deteriorating.

However, when discussing alignment, it should be noted that alignment does not exist a priori, but is made, optimized, weakened, or found to be unrealizable in the interactional translation process between both human and non-human actants. Alignment is made tangible in documents such as a feasibility study, a change in the land zoning plan, or an environment permit.

\subsection{More of a Beneficial than an Obligatory Passage Point}

An energy initiative does not have much leverage over other parties when it starts its innovation project because, as a new and developing organization, it generally does not have much power or resources. This dependence is often one-sided, and the initiative can therefore be used instrumentally by others in the actor network. When better opportunities occur, interest in the local energy project may fade, as happened with the solar project at the landfill site when the thin-film developer encountered better opportunities abroad and the pilot test results were disappointing.

In general, it appears to be challenging for local energy initiatives to make themselves indispensable to the entities that they need to develop and implement their technological innovation, i.e., to be an obligatory passage point that others in the network need to cross to achieve their goals. It is often not possible for initiatives to present themselves as an obligatory point of passage to, for instance, the owner of a potential project site or a bank. Commitment to the socio-technical network then needs 
to be established by being more of a beneficial point of passage than an obligatory one, which makes the interessement devices even more important.

\subsection{Place-Based Versus Up-Scalable Innovative Technological Configurations}

The case studies show that it is more feasible for a cooperative to create a local innovative technological configuration than to bring a technology that is developed as part of or for such a configuration to the market. It is very challenging and probably not even desirable for an energy initiative to professionalize and to create a suitable actor network with the required time, knowledge, and capital that could bear the risk of developing a technology and bringing it to the market.

However, partnering can be interesting for energy initiatives that do not find a proven technology that fits their project. For technological developers, it can be equally attractive to partner with an energy initiative in order to work with a party that will actively consider the specifications required for their innovations and implementation to succeed, and which has local networks, knows which locations are likely acceptable for projects, and invests the necessary time and effort into a pilot project. In addition, it can be interesting for technology developers to seek out a local energy initiative as a launch customer. Some innovation grants require working with a civil society organization, as was the case for the innovation grant that the solar project consortium for the landfill site was granted.

\subsection{Reflections on the Value of ANT for Understanding the Dynamics of Grassroots Technological Innovations}

The ANT conceptual lens allowed for a rich and detailed analysis of local network dynamics. Following the actants is useful for analyzing local grassroots innovations, as each local context and each particular technology implies a specific constellation of networked actants. The translation dynamics highlight the changing roles and identities of these actants during network-building. The new technological configuration is understood as an outcome of translation dynamics shaped in the local process of alignment, and stabilization and destabilization of networks.

More concretely, ANT enabled us to follow energy initiatives and the waxing and waning of the actor networks that they established to engage actants who could fulfil roles such as site, energy generator, inventor, connector (e.g., intermediary), advocate, authority, or provider of various other resources. Many actants were intentionally engaged by the initiatives, but others created a role for themselves, desired or undesired. Sometimes this concerned human actants, such as the RWS, who invited the floating solar start-up to run a pilot project, and other times these were non-human actants such as the lake wildlife, archaeological remains, and the weather conditions that damaged the energy generation technology. Moreover, it is typical of translation processes that actants are changed. For instance, both sites changed their identity from useless wasteland to RE generation sites and symbols of local sustainability, and the Landfill and Soil Protection Decree was translated by the efforts of the grassroots innovators and finally the Province from being an inhibiting actant to an enabling one.

Furthermore, using ANT, we were able to consider the roles of material and human actants equally in the network building processes of adjustment, molding, trying to connect, and misalignment. The success or failure of local innovative configurations, and thereby their potential to contribute to local and supra-local energy transitions, is shaped through these processes. When a project or technology development is started by advocates for energy transition, and has a heightened sensitivity to the identity and agency of other material and social actants, innovative technological configurations of various kinds are more likely to have high potential for developing synergies with their implementation context. Because they are included in the local context, energy initiatives are well-positioned to contribute to the creation of such synergies.

\subsection{Suggestions for Further Research}

Our study has analyzed how local technological innovations are shaped through micro level socio-technical network dynamics. We specifically aimed to enrich the literature on the project-level 
processes of building networks that give rise to and stabilize new innovative configurations. Here we want to raise three topics that, in our opinion, are worthwhile for further study.

The first topic is to compare our cases with other cases of local technological innovation, preferably in other countries. This would contribute to a larger evidence base of grassroots technological innovation dynamics, but would also allow for more insight into the location-innovation relation. Due to the large role of local actants and local conditions in the innovation process, literature on frugal innovation could offer useful concepts for such research [38]. Grassroots innovation too starts off resource-constrained and asks for smart solutions to make the most of what is available.

Second, as we focused on the emergence of innovations, transfer and diffusion of grassroots technological innovation was not within our scope. Mainstreaming grassroots innovation often involves input from, and hybridization with, more conventional research, development, and investment in institutions for science, technology, and marketing [2,39]. Accordingly, recontextualization and up-scaling of local innovations may very well imply broadening networks. The triple and quadruple helix model of innovation could offer conceptual guidance in understanding relationships that are formed between civil society actors such as energy initiatives, businesses, governments, and knowledge institutions [40,41].

Third, the institutional conditions appeared to be crucial for configuring the studied innovations. A few studies have explored the fit between the activities of local energy initiatives, and national and regional policies and governance [42-44]. It would be interesting to see more research into policies that are specifically developed to enable more types of experimentation with novel local energy configurations [45].

Author Contributions: Conceptualization: E.C.v.d.W., H.J.v.d.W., and E.C.J.v.O.; Data curation: E.C.v.d.W.; Formal analysis, E.C.v.d.W.; Funding acquisition: H.J.v.d.W. and E.C.J.v.O.; Investigation: E.C.v.d.W.; Methodology: E.C.v.d.W. and E.C.J.v.O.; Project administration: H.J.v.d.W. and E.C.J.v.O.; Supervision: H.J.v.d.W. and E.C.J.v.O.; Writing original draft: E.C.v.d.W.; Writing review and editing: E.C.v.d.W., H.J.v.d.W., and E.C.J.v.O.

Funding: This research and the APC were funded by The Netherlands Organisation for Scientific Research (NWO) grant number [313-99-304].

Acknowledgments: We would like to thank Anne Marieke Schwencke for helping to identify suitable cases; all the interviewees for generously sharing their time, experiences, and knowledge; and Eveline de Smalen and two professional correctors for grammar and style improvements. We would also like to thank the anonymous reviewers for their critical and constructive feedback.

Conflicts of Interest: The authors declare no conflict of interest. The funders had no role in the design of the study; in the collection, analyses, or interpretation of data; in the writing of the manuscript; or in the decision to publish the results.

\section{Appendix A. Key Actors and Method of Interviewing}

This appendix presents Table A1 with the key actors and interview methods.

Table A1. Key actors and interview methods.

\begin{tabular}{|c|c|c|c|}
\hline $\begin{array}{l}\text { Case 1: Solar at the Eerbeek } \\
\text { Landfill Site }\end{array}$ & $\begin{array}{l}\text { Type of Interview } \\
(F=\text { Face to Face, } P=\text { Phone, } \\
X=\text { Not Interviewed) }\end{array}$ & $\begin{array}{l}\text { Case 2: Floating, Rotating Solar } \\
\text { in Elst }\end{array}$ & $\begin{array}{l}\text { Type of Interview } \\
\text { ( } \mathrm{F}=\text { Face to Face, } \mathrm{P}=\text { Phone) }\end{array}$ \\
\hline Local government & $\mathrm{F}$ & Local government & $\mathrm{P}$ \\
\hline Distribution system operator * & $\mathrm{F}$ & Distribution system operator * & $\mathrm{F}$ \\
\hline Provincial government * & $\mathrm{P}$ & Provincial government * & $\mathrm{P}$ \\
\hline Landfill site manager & $\mathrm{P}$ & Start-up & $\mathrm{F}$ \\
\hline Thin-film developer ** & $x$ & Manager industrial estate & $\mathrm{P}$ \\
\hline
\end{tabular}

* Same actor, as the cases are in the same province and in the area of a single distribution system operator. Both cases were covered during the same meeting. ${ }^{* *}$ These actors were not available for interview due to their busy schedules. The information about their roles has been recovered from interviews with the actors with which they interacted. 


\section{References}

1. Ornetzeder, M.; Rohracher, H. Of solar collectors, wind power, and car sharing: Comparing and understanding successful cases of grassroots innovations. Glob. Environ. Chang. 2013, 23, 856-867. [CrossRef]

2. Seyfang, G.; Smith, A. Grassroots innovations for sustainable development: Towards a new research and policy agenda. Environ. Politics 2007, 16, 584-603. [CrossRef]

3. Smith, A.; Stirling, A. Innovation, sustainability and democracy: An analysis of grassroots contributions. J. Self-Gov. Manag. Econ. 2018, 6, 64-97.

4. Hilmi, M.F. Grassroots Innovation from the Bottom of the Pyramid. Curr. Opin. Creat. Innov. Entrep. 2012, 1, 1-3. [CrossRef]

5. Ornetzeder, M.; Rohracher, H. User-led innovations and participation processes: Lessons from sustainable energy technologies. Energy Policy 2006, 34, 138-150. [CrossRef]

6. Garud, R.; Karnoe, P. Bricolage vs. breakthrough: Distributed and embedded ageny in technology entrepreneurship. Res. Policy 2003, 32, 277-300. [CrossRef]

7. Lavrijssen, S.; Carrillo Parra, A.; Lavrijssen, S.; Carrillo Parra, A. Radical Prosumer Innovations in the Electricity Sector and the Impact on Prosumer Regulation. Sustainability 2017, 9, 1207. [CrossRef]

8. Schot, J.; Kanger, L.; Verbong, G. The roles of users in shaping transitions to new energy systems. Nat. Energy 2016, 1, 16054. [CrossRef]

9. Smith, A.; Hargreaves, T.; Hielscher, S.; Martiskainen, M.; Seyfang, G. Making the most of community energies: Three perspectives on grassroots innovation. Environ. Plan. A 2015, 48, 407-432. [CrossRef]

10. Koirala, B.P.; van Oost, E.; van der Windt, H. Community energy storage: A responsible innovation towards a sustainable energy system? Appl. Energy 2018, 231, 570-585. [CrossRef]

11. Martiskainen, M. The role of community leadership in the development of grassroots innovations. Environ. Innov. Soc. Transit. 2017, 22, 78-89. [CrossRef]

12. Acosta, C.; Ortega, M.; Bunsen, T.; Koirala, B.P.; Ghorbani, A. Facilitating energy transition through energy commons: An application of socio-ecological systems framework for integrated community energy systems. Sustainability 2018, 10, 366. [CrossRef]

13. De Vries, G.W.; Boon, W.P.C.; Peine, A. User-led innovation in civic energy communities. Environ. Innov. Soc. Transit. 2016, 19, 51-65. [CrossRef]

14. Morris, L. The Innovation Master Plan: The CEO's Guide to Innovation; Innovation Academy: Walnut Creek, CA, USA, 2011; ISBN 9780615512020.

15. Schot, J.; Geels, F.W. Strategic niche management and sustainable innovation journeys: Theory, findings, research agenda, and policy. Technol. Anal. Strat. Manag. 2008, 20, 537-554. [CrossRef]

16. Hargreaves, T.; Hielscher, S.; Seyfang, G.; Smith, A. Grassroots innovations in community energy: The role of intermediaries in niche development. Glob. Environ. Chang. 2013, 23, 868-880. [CrossRef]

17. Seyfang, G.; Hielscher, S.; Hargreaves, T.; Martiskainen, M.; Smith, A. A grassroots sustainable energy niche? Reflections on community energy in the UK. Environ. Innov. Soc. Transit. 2014, 13, 21-44. [CrossRef]

18. Dóci, G.; Vasileiadou, E.; Petersen, A.C. Exploring the transition potential of renewable energy communities. Futures 2015, 66, 85-95. [CrossRef]

19. Smith, A.; Voß, J.P.; Grin, J. Innovation studies and sustainability transitions: The allure of the multi-level perspective and its challenges. Res. Policy 2010, 39, 435-448. [CrossRef]

20. Latour, B. Pandora's Hope: Essays on the Reality of Science Studies; Harvard University Press: Cambridge, MA, USA, 1999; ISBN 9780674653368.

21. Callon, M. Some elements in the sociology of translation: Domestication of the scallops and the fishermen of St. Brieuc Bay. Power Action Belief A New Sociol. Knowl. 1986, 196-223. [CrossRef]

22. Law, J.; Callon, M. Engineering and Sociology in a Military Aircraft Project: A Network Analysis of Technological Change. Soc. Probl. 1988, 35, 284-297. [CrossRef]

23. Callon, M. Struggles and Negotiations to Define what is Problematic and what is not: The Socio-logic of Translation. In The Social Process of Scientific Investigation; Knorr, K., Krohn, R., Whitley, R., Eds.; Reidel Publishing Co.: Dordecht, The Netherlands, 1981; pp. 197-219.

24. Davies, A.R. Power, politics and networks: Shaping partnerships for sustainable communities. Area 2002, 342, 190-203. [CrossRef] 
25. Sayes, E. Actor-Network Theory and methodology: Just what does it mean to say that nonhumans have agency? Soc. Stud. Sci. 2014, 44, 134-149. [CrossRef] [PubMed]

26. Boon, F.P. Local Is Beautiful: The Emergence and Development of Local Renewable Energy Organisations. Master's Thesis, University of Utrecht, Utrecht, The Netherlands, August 2012.

27. Fleck, J. Configurations: Crystallizing contingency. Int. J. Hum. Factors Manuf. 1993, 3, 15-36. [CrossRef]

28. Peine, A. Understanding the dynamics of technological configurations: A conceptual framework and the case of Smart Homes. Technol. Forecast. Soc. Chang. 2009, 76, 396-409. [CrossRef]

29. Fraunhofer ISE Photovoltaics Report. Available online: https://www.ise.fraunhofer.de/content/dam/ise/ de/documents/publications/studies/Photovoltaics-Report.pdf (accessed on 28 June 2018).

30. Besluit stortverbod afvalstoffen (27 June 1995). Available online: https:/ / zoek.officielebekendmakingen.nl/ stb-1995-345.html (accessed on 28 June 2018).

31. Stortbesluit bodembescherming (20 January 1993). Available online: http://wetten.overheid.nl/ BWBR0005858/2016-07-01 (accessed on 28 June 2018).

32. Crisis en Herstelwet (18 March 2010). Available online: http:// wetten.overheid.nl/BWBR0027431/2017-0516 (accessed on 29 July 2018).

33. Besluit uitvoering crisis- en herstel wet tiende tranche (14 August 2015). Available online: https: / / zoek. officielebekendmakingen.nl/stb-2015-323.html (accessed on 28 June 2018).

34. De Boer, J.; Zuidema, C. Integrated energy landscapes: How coevolution encourages planners to focus on developing linkages between renewable energy systems and local landscapes. In Spatial Planning in a Complex Unpredictable World of Change; De Roo, G., Boelens, L., Eds.; InPlanning: Groningen, The Netherlands, 2016; pp. 170-184.

35. Warren, C.R.; McFadyen, M. Does community ownership affect public attitudes to wind energy? A case study from south-west Scotland. Land Use Policy 2010, 27, 204-213. [CrossRef]

36. Musall, F.D.; Kuik, O. Local acceptance of renewable energy-A case study from southeast Germany. Energy Policy 2011, 39, 3252-3260. [CrossRef]

37. Hoppe, T.; Graf, A.; Warbroek, B.; Lammers, I.; Lepping, I. Local governments supporting local energy initiatives: Lessons from the best practices of Saerbeck (Germany) and Lochem (The Netherlands). Sustainability 2015, 7, 1900-1931. [CrossRef]

38. Numminen, S.; Lund, P.D. Frugal energy innovations for developing countries-A framework. Glob. Chall. 2017, 1, 9-19. [CrossRef]

39. Fressoli, M.; Arond, E.; Abrol, D.; Smith, A.; Ely, A.; Dias, R. When grassroots innovation movements encounter mainstream institutions: Implications for models of inclusive innovation. Innov. Dev. 2014, 4, 277-292. [CrossRef]

40. McAdam, M.; Debackere, K. Beyond 'triple helix' toward 'quadruple helix' models in regional innovation systems: Implications for theory and practice. RED Manag. 2018, 48, 3-6. [CrossRef]

41. Brink, T.; Madsen, S.O. The triple helix frame for small- and medium-sized enterprises for innovation and development of offshore wind energy. Triple Helix 2016, 3, 4. [CrossRef]

42. Kooij, H.-J.; Oteman, M.; Veenman, S.; Sperling, K.; Magnusson, D.; Palm, J.; Hvelplund, F. Between grassroots and treetops: Community power and institutional dependence in the renewable energy sector in Denmark, Sweden and the Netherlands. Energy Res. Soc. Sci. 2018, 37, 52-64. [CrossRef]

43. Oteman, M.; Wiering, M.; Helderman, J.-K. The institutional space of community initiatives for renewable energy: A comparative case study of the Netherlands, Germany and Denmark. Energy Sustain. Soc. 2014, 4, 11. [CrossRef]

44. Warbroek, B.; Hoppe, T. Modes of Governing and Policy of Local and Regional Governments Supporting Local Low-Carbon Energy Initiatives; Exploring the Cases of the Dutch Regions of Overijssel and Fryslân. Sustainability 2017, 9, 75. [CrossRef]

45. De Boer, J.; Zuidema, C.; Van Hoorn, A.; De Roo, G. The adaptation of Dutch energy policy to emerging area-based energy practices. Energy Policy 2018, 117, 142-150. [CrossRef]

(C) 2018 by the authors. Licensee MDPI, Basel, Switzerland. This article is an open access article distributed under the terms and conditions of the Creative Commons Attribution (CC BY) license (http:/ / creativecommons.org/licenses/by/4.0/). 